\title{
My encounter with RNA
}

\section{YUKIHIDE TOMARI}

Institute of Molecular and Cellular Biosciences, Department of Medical Genome Sciences, The University of Tokyo, Tokyo 113-0032, Japan

Twenty years ago, I was a freshman in the liberal arts college of The University of Tokyo, knowing nothing about the beauty of RNA. I did not even imagine that I would someday be a biologist. At that time, I was more interested in electronics and mechanical engineering and computer science. Moreover, I was pretty busy playing the keyboard in jazz, funk and fusion bands. Coincidentally, however, a molecular biology class I casually took in my sophomore year captured my heart. Fascinated by life as exquisite molecular machinery, I decided to enter Department of Chemistry and Biotechnology. Coincidentally again, I was assigned to Dr. Kimitsuna Watanabe's lab, working on the genetic code and tRNAs, for my undergraduate thesis in 1997. My involvement in RNA started almost by accident, but I feel tremendously fortunate for this wonderful encounter.

I studied the molecular mechanism of the enzyme tRNA nucleotidyltransferase or CCA-adding enzyme, which builds the sequence CCA onto the $3^{\prime}$ end of tRNA, for my graduate thesis. My graduate work has provided me a broad range of skills for the biochemical analysis of RNA enzymes. When I was considering my future career after my Ph.D., the most interesting - and most uncharacterized-RNA enzyme for me was that which catalyzes RNA interference (RNAi), a gene-silencing phenomenon directed by double-stranded RNAs. Back then, understanding of the cellular roles of RNAs had already been revolutionized by the seminal Nature 1998 paper on RNAi by Drs. Andrew Fire and Craig Mello, but remarkably little was known about its biochemical mechanism. One day, I encountered an amazingly beautiful and meticulous paper on the role of ATP in the RNAi pathway by Dr. Phillip Zamore and colleagues. I was so excited that I immediately e-mailed him—without thinking it through—-to ask if there were any postdoc positions available. In April 2003, I joined the Zamore lab and started working on RNAi and related RNA silencing phenomena. My life at UMASS Medical School in Worcester, MA was simply exciting, with great science, great people, heavy snow and a new family member. I learned a lot in the Zamore lab, but most importantly, I learned how best to tackle and enjoy science. I also enjoyed

\footnotetext{
Corresponding author: tomari@iam.u-tokyo.ac.jp

Article and publication date are at http://www.rnajournal.org/cgi/doi/10. 1261/rna.050278.115. Freely available online through the RNA Open Access option.
}

playing the keyboard in local bands in MA. I remember my four years in Worcester as if they were yesterday.

It has been eight years since I was lucky enough to start my own lab back in Tokyo. For me, the most interesting RNA enzyme is still the RNA-induced silencing complex (RISC), composed of Argonaute family proteins and small RNAs. RISC feeds my fascination for exquisite molecular machinery, just like my molecular biology class did 19 years ago. Assembly of RISC is not merely a direct association of Argonaute and a small RNA but rather follows an ordered, multi-step path with the help of the Hsc70/Hsp90 chaperones. Once assembled, RISC mediates cleavage of target mRNAs as well as their translational repression, deadenylation and degradation by recruiting downstream silencing factors. Previous biochemical and structural studies have suggested dynamic, conformational changes of both Argonaute and the small RNA during assembly and function of RISC. I would like to understand or "see" the vibrant interplay in motion between Argonaute, small RNAs and other cofactors. To this end, our group as well as other groups recently started utilizing a single-molecule imaging technique to monitor the assembly and function of RISC in real time. This was made possible because the entire RNAi pathway can be robustly recapitulated in a cell-free system.

In fact, "classical" biochemistry-in vitro recapitulation, purification and reconstitution-has contributed significantly to our understanding of RNA silencing as well as its application, although of course the importance of genetics, cell biology and "modern" molecular biology like co-immunoprecipitation cannot be overstated. The field of RNA silencing has been lucky in a sense that RNAi was successfully recapitulated in crude lysate from Drosophila embryos by Drs. Thomas Tuschl and Phillip Zamore in as early as 1999, only one year after the discovery of RNAi in animals. In contrast, full recapitulation has not yet been achieved for some small RNA classes like PIWI-interacting RNAs (piRNAs) and for long non-coding RNAs. A major reason for this difficulty, I think, is that special cellular "platforms" (e.g., nuage for piRNAs and nuclear speckles for many long non-coding RNAs) are essential for those RNAs to function; once cells are lysed for in vitro studies, the platforms are lost or disturbed.

(C) 2015 Tomari This article, published in RNA, is available under a Creative Commons License (Attribution-NonCommercial 4.0 International), as described at http://creativecommons.org/licenses/by-nc/4.0/. 
The future challenges will be to reconstruct the functional platform for each non-coding RNA class in a cell-free system, and the formation of hydrogel-like structures by RNA-binding proteins with low complexity sequence domains, as recently reported by Dr. Steven McKnight's group, may give us a clue.

As described above, I started my career as an RNA biologist by working on tRNAs ( $\sim 76 \mathrm{nt}$ in length), and have more recently been studying small silencing RNAs ( $\sim 21 \mathrm{nt})$. After all, I have so far only dealt with relatively short, noncoding RNAs; not "regular" mRNAs. And yet, there are still so many unknowns that inevitably evoke my interest. Solving one problem just generates many more questions to be answered. To be frank, I'm sure I would also enjoy working on topics unrelated to RNAs. However, I predict I will still be working on RNAs - although their lengths are unpredictable-20 years from now (I'll be nearly 60 then). RNA is so fundamental and linked to virtually every biological pathway, and I don't see any reason for exciting questions to dry up in this field. With that in mind, I look forward to celebrating the 40th anniversary of RNA. 

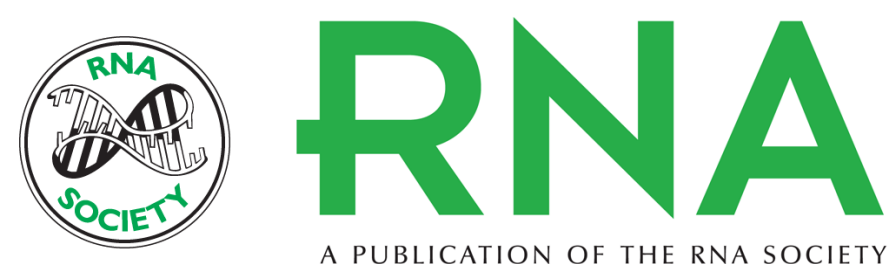

A PUBLICATION OF THE RNA SOCIETY

\section{My encounter with RNA}

Yukihide Tomari

RNA 2015 21: 747-748

Open Access Freely available online through the RNA Open Access option.

Creative This article, published in RNA, is available under a Creative Commons License

Commons (Attribution-NonCommercial 4.0 International), as described at

License http://creativecommons.org/licenses/by-nc/4.0/.

Email Alerting Receive free email alerts when new articles cite this article - sign up in the box at the Service top right corner of the article or click here. 